\title{
Transformasi Unsur Fisik Pembentuk Sumbu di dalam Alun-Alun Terhadap Kompleks Pemerintah di Jawa
}

\author{
Ayesha Aramita Malonda ${ }^{1}$ an Yohanes Karyadi Kusliansjah ${ }^{2}$ \\ ${ }^{1}$ Mahasiswa Program Magister Arsitektur, Universitas Katolik Parahyangan \\ ${ }^{2}$ Dosen Program Magister Arsitektur, Universitas Katolik Parahyangan \\ 1aaramarley@yahoo.com, 2karyadi@unpar.ac.id
}

\begin{abstract}
ABSTRAK
Alun-alun pada masa lalu merupakan satu kesatuan dengan kompleks Keraton dan berada dalam sebuah sumbu. Unsur fisik pembentuk sumbu di dalam alun-alun adalah dua pohon beringin yang membentuk orientasi terhadap kompleks pemerintah (Keraton). Seiring perkembangan, alun-alun direvitalisasi untuk menyesuaikan kondisi budaya saat ini dan untuk meningkatkan kualitas ruang alun-alun sebagai identitas kota. Penelitian ini bertujuan untuk mengetahui representasi unsur fisik pembentuk sumbu di dalam alun-alun terhadap kompleks pemerintah. Teori Habraken tentang tatanan fisik (physical order) dianggap mampu untuk membedah unsur fisik pembentuk alun-alun dan membawa pada kesimpulan dari penelitian ini. Hal-hal yang perlu diidentifikasi untuk mencapai tahap interpretasi adalah identifying level pada nominal classes, yaitu major arteries, roads, building elements, partitioning, furniture, body dan utensils. Hasil penelitian menunjukkan sumbu alun-alun terhadap kompleks pemerintah saat ini ditunjukkan dengan wujud fisik berupa peletakkan perabot dalam satu sumbu, pembentukkan pathways, pengerasan tanah pada area entrance utama dan penambahan gerbang di dalam alun-alun. Kesimpulan penelitian ini bahwa pada masa lalu, sumbu alun-alun terhadap kompleks pemerintah terbentuk karena kepercayaan dan makna-makna simbolik dari kehidupan budayanya. Saat ini sumbu terbentuk dari unsur fisik pelengkap sarana/prasarana kegiatan ekonomi dan sosial sebagai representasi sumbu di dalam alun-alun terhadap kompleks pemerintah.
\end{abstract}

Kata kunci: transformasi unsur fisik, sumbu alun-alun, kompleks pemerintah, pulau Jawa

ABSTRACT

In the past, Alun-alun is united with the Keraton complex and present in an axis. The physical elements which forms an axis in Alun-alun are the two banyan trees that form the orientation towards the government complex (Keraton). As the development progresses, Alun-alun is revitalized to adjust current cultural conditions and to improve the quality of the Alun-alun's hall as the city's identity. This research aimed to determine the representation of physical elements which formed an axis in Alunalun towards the government complex. Habraken's theory on the physical order was considered adequate to dissect the physical elements which formed Alun-alun and lead to the conclusion of this research. Matters that needs to be identified to reach the interpretation stage were identifying levels in nominal classes, namely major arteries, roads, building elements, partitioning, furniture, bodies and utensils. The results indicated that the axis of Alun-alun towards the current government complex was indicated by the physical form of locating the furniture in one axis, forming the pathways, the hardening of soil at the main entrance area and the addition of gates inside Alun-alun. The conclusion of this research was that in the past, the axis of Alun-alun towards the government complex was formed by the belief and symbolic meanings of its cultural life. Currently the axis was formed from the physical element of complementary facilities or infrastructure of economic and social activities as a representation of the axis in Alun-alun towards the government complex.

Keywords: transformation of physical element, axis of alun-alun, government complex, Java island 


\section{Pendahuluan}

Alun-alun pada masa Majapahit berada dalam posisi sentral bersama Keraton sebagai pusat pemerintah. Pada masa Mataram, dapat dilihat di Yogyakarta dan Surakarta, posisi alun-alun dan Keraton berada dalam sebuah sumbu yang terbentuk dari ruang-ruang di dalam Kompleks Keraton, pohon beringin yang berada di dalam alun-alun, serta kepercayaan terhadap gunung di Utara dan laut di Selatan. Pada masa Kolonial pohon beringin tetap dihadirkan dalam alun-alun berjumlah dua dan terkadang satu. Kehadiran pohon beringin pada masa kolonial tidak terlalu mencerminkan sebagai unsur fisik pemebentuk sumbu.

Saat ini, alun-alun berada dalam kendali penguasa yaitu pemerintah kota yang berhak melakukan perubahan-perubahan dalam ruang alun-alun. Pemahaman terhadap alun-alun cenderung berubah menjadi ruang publik dengan kehadiran lapangan olahraga dan kegiatan rekreasi. Tetapi terdapat pemahaman lain tentang orientasi ruang alun-alun. Pembentukkan pathways di dalam alun-alun, pengolahan tanah, serta peletakkan perabot tambahan yang hadir saat ini, sengaja atau tidak disengaja menekankan pada sisi tertentu dan akhirnya membentuk orientasi ruang di dalam alun-alun. Penekanan tersebut dapat dilihat sebagai hasil bentuk respon terhadap jalan ataupun bangunan dengan hirarki tertinggi yang mengelilingi alun-alun, salah satunya adalah kompleks pemerintah.

Dapat ditarik kesimpulan, bahwa unsur fisik di dalam alun-alun saat ini hadir tidak semata-mata untuk mempercantik wajah alun-alun, namun peletakkannya dapat memberikan pemahaman tentang orientasi ruang. Pada kasus alun-alun yang masih bersandingan dengan pusat pemerintah, dapat memiliki dua kemungkinan, masih mengikuti konsep masa lalu (dimana alun-alun berorientasi terhadap kompleks pemerintah yaitu Keraton) atau sudah memiliki orientasi ke ruang selain kompleks pemerintah.

\section{Bahan dan Metode}

Orientasi ruang di dalam alun-alun dapat dilihat dari unsur fisik pembentuknya seperti yang dikemukakan Habraken dalam memahami transformasi lingkungan binaan. Menurut Habraken bahwa setiap lingkungan binaan yang akan diteliti harus memiliki batasan, dalam penelitian ini alun-alun dan kompleks pemerintah dilihat sebagai satu kesatuan tapak yang akan diamati. Tapak dalam batas penelitian memiliki unsur fisik pembentuk lingkungan yang dibedah menggunakn teori Habraken tentang tatanan fisik (physical order). Tahap penelitian diawali dengan mengidentifikasi level (identifying level) setiap unsur fisik pada nominal classe yaitu, major arteries, roads, building element, partitioning, furniture dan body \& utensils.

Major arteries diadaptasi sebagai jalan utama yang mengelilingi alun-alun maupun yang menghubungkan alun-alun dan kompleks pemerintah. Roads di adaptasi sebagai jalan di dalam alun-alun atau pathways (dapat berupa jalan pedestrian dan jalan kendaraan. Building elements dilihat dari pengolahan pengerasan tanah ataupun rumput yang dipandang sebagai alas permukaan(pada masa lalu dikatakan bahwa alas alun-alun berupa pasir). Selain alas, terdapat dinding yang di adaptasi sebagai pagar maupun gerbang dalam alun-alun. Partitioning di adaptasi sebagai pagar atau dapat berupa deretan pohon yang membentuk ruang di dalam ruang alun-alun. Furniture di adaptasi sebagai pendopo di dalam alun-alun sebagai tempat berteduh dan beristirahat para pengguna alun-alun. Di beberapa waktu tertentu, pendopo di dalam alun-alun berfungsi sebagai tempat para pejabat duduk mengikuti acara-acara kenegaraan. Utensils di adaptasi sebagai pohon beringin, tiang bendera, monumen/tugu dan signage.

Pemilihan kasus studi dalam penelitian ini adalah alun-alun yang masih bersandingan dengan pusat pemerintah di Pulau Jawa karena dianggap masih sesuai dengan konsep masa lalu. Terpilih lah empat (4) Kota dan empat puluh (40) Kabupaten yang ada di Pulau Jawa 
meliputi, Salatiga, Tegal, Blitar dan Malang (Tugu) sebagai Ibukota Provinsi, serta Bantul, Wonosari, Cianjur, Subang, Indramayu, Majalengka, Banjarnegara, Batang, Boyolali, Cilacap, Jepara, Karanganyar, Kebumen, Kendal, Kudus, Pati, Kajen (Pekalongan), Pemalang, Purblaingga, Purworejo, Sragen, Slawi, Wonogiri, Wonosobo, Bondowoso, Jember, Jombang, Lamongan, Lumajang, Magetan, Nganjuk, Ngawi, Pacitan, Ponorogo, Sidoarjo, Trenggalek, Tubang dan Rangkasbitung sebagai Kota Kabupaten. Pulau Jawa merupakan pusat beberapa kerajaan Hindu-Buddha, kesultanan Islam, pemerintahan kolonial Hindia-Belanda, serta pusat pergerakan kemerdekaan Indonesia. Sehingga alun-alun di Pulau Jawa dianggap sesuai mempresentasikan transformasi dari beberapa periode hasil perkembangan kota.

\section{Hasil Temuan}

Sumbu yang terbentuk pada masa lalu berupa unsur fisik maupun non-fisik, dimana unsur fisik dan non-fisik tersebut juga memiliki makna simbolik sesuai kepercayaan yang berlaku di masyarakat. Saat ini, sumbu pengikat antara ruang alun-alun dan pemerintah lebih diperlihatkan oleh unsur fisik, berupa elemen simbolik ataupun pengolahan bentuk fisik.

Orientasi ruang antara pemerintah dan alun-alun diperkuat dengan pengolahan bentuk fisik alun-alun; peletakkan perabot (pohon beringin, tiang bendera, monumen/tugu, signage), pengerasan tanah pada sisi tertentu atau yang berhadapan dengan pusat pemerintah, pathways yang memberikan arah seperti pada konsep masa lalu bahwa rakyat berjalan ditengah alun-alun menuju pusat pemerintahan, keberadaan pendopo di dalam alunalun sebagai bentuk adaptasi dari paseban (ruang tunggu tamu di alun-alun sebelum bertemu raja) atau juga sebagai bentuk adaptasi siti hinggil (tempat pemimpin pemerintah menonton atau melihat pertunjukkan di alun-alun, dimana saat ini apabila diadakan upacara kenegaraan, para pemimpin berada di posisi pendopo alun-alun berada).

\subsection{Pusat Pemerintah}

Pada era kerajaan dahulu pusat pemerintahan ini sering disebut dengan Istana, Kedhaton yang ditempati oleh Raja dan keluarganya bersifat sakral. Kawasan pusat pemerintahan dimasa silam berada di sisi Utara pada masa Kerajaan dan Utara-Selatan pada masa Kolonial. Saat ini pendopo kabupaten tidak dapat dikatakan sebagai bagian dari pusat pemerintah, dikarenakan sudah beralih fungsi dimana dibuka untuk keperluan umum, sebagian menjadi museum yang merubah hierarki ruang menjadi semipublik ataupun publik. Pada penelitian ini, yang termasuk dalam pusat pemerintah adalah kantor pemerintah tertinggi ataupun sebuah kompleks yang di dalamnya terdapat penguasa tertinggi pada sebuah kota/kabupaten yaitu kantor Walikota dan kantor Bupati.Posisi pusat pemerintah perlu untuk diketahui untuk pemahaman orientasi ruang di dalam alun-alun.

\section{Tabel 1. Posisi Pemerintah Tertinggi terhadap Alun-Alun di Pulau Jawa}

Bantul,Wonosari,Cilacap,
$\begin{gathered}\text { Kudus,Pati,Purbalingga, } \\ \text { Sragen,Pacitan }\end{gathered}$




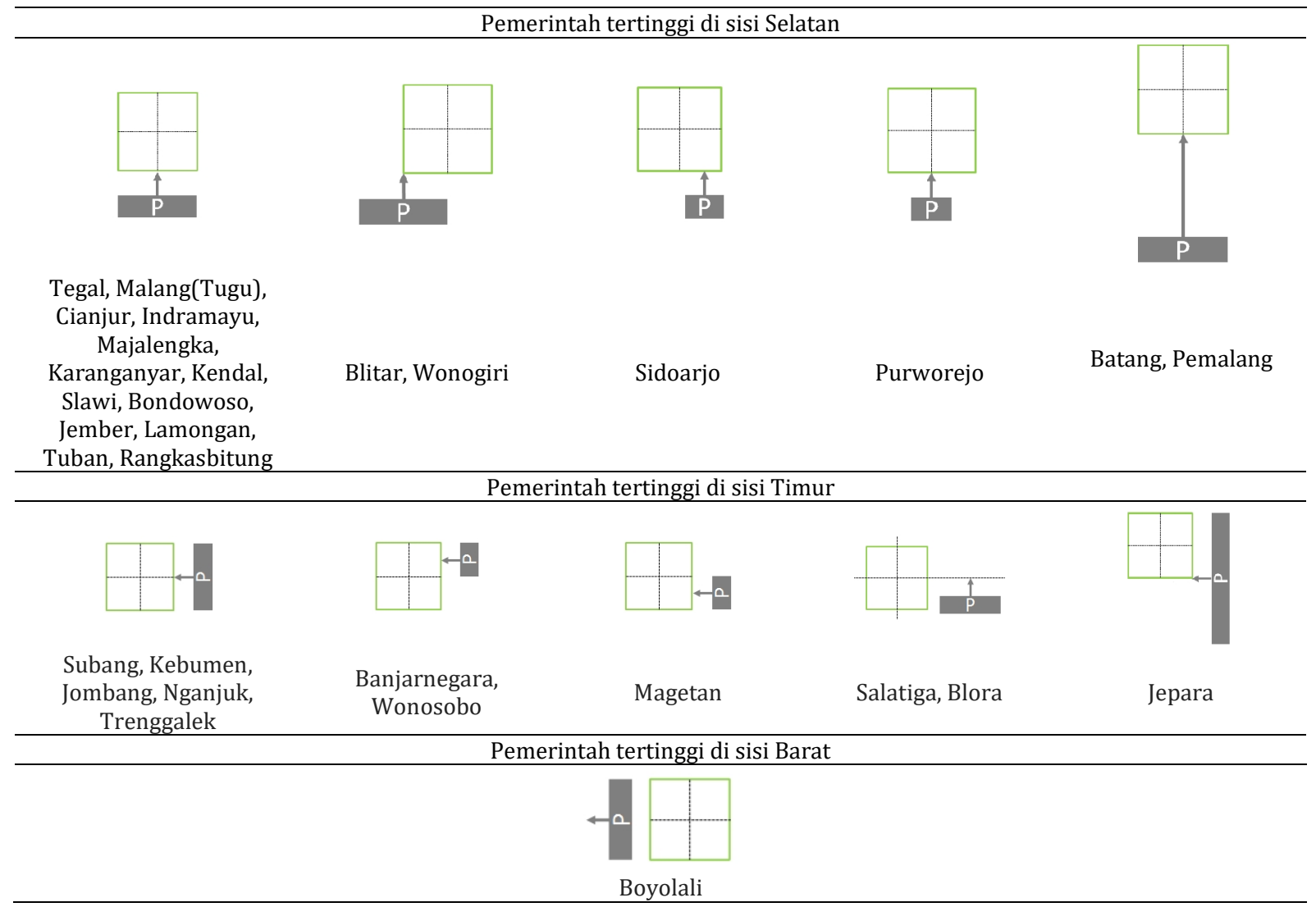

\subsection{Pohon Beringin}

Pada masa prakolonial terdapat dua buah pohon beringin di dalam alun-alun yang memperkuat orientasi terhadap Keraton sebagai pusat pemerintah. Rakyat atau tamu yang ini bertemu raja, berjalan di tengah pohon beringin yang diartikan juga sebagai gerbang menuju Keraton. Posisi dua pohon beringin tersebut dapat dikatakan sebagai unsur pembentuk sumbu yang berdiri di dalam alun-alun. Pada masa kolonial juga memiliki pohon beringin terkadang dua ataupun satu pohon beringin. Pohon beringin pada masa kolonial merupakan kebertahan konsep alun-alun masa prakolonial. Saat ini beberapa alun-alun pun masih memiliki pohon beringin, tetapi tidak selamanya berada di tengah alun-alun, jumlahnya pun bervariasi. Pohon beringin merupakan elemen simbolik yang kuat dalam memepengaruhi sebuah sumbu dikarenakan nilai kesejarahannya dan kepercayaan masyarakat tentang pohon beringin memiliki kekuatan mistis. Berikut ini adalah variasi posisi pohon beringin yang ditemukan dalam kasus studi.

Tabel 2. Posisi Pohon Beringin

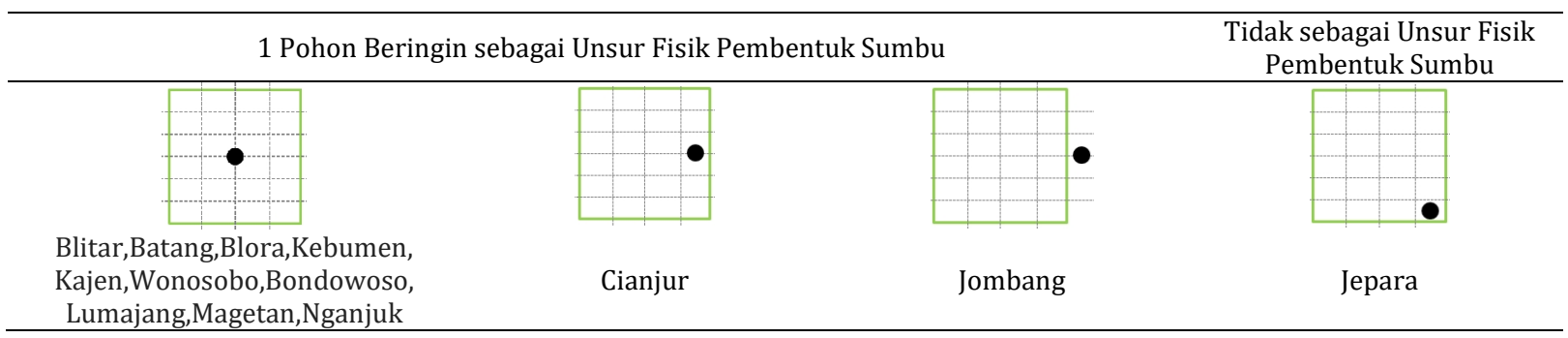


2 Pohon Beringin sebagai Unsur Fisik Pembentuk Sumbu

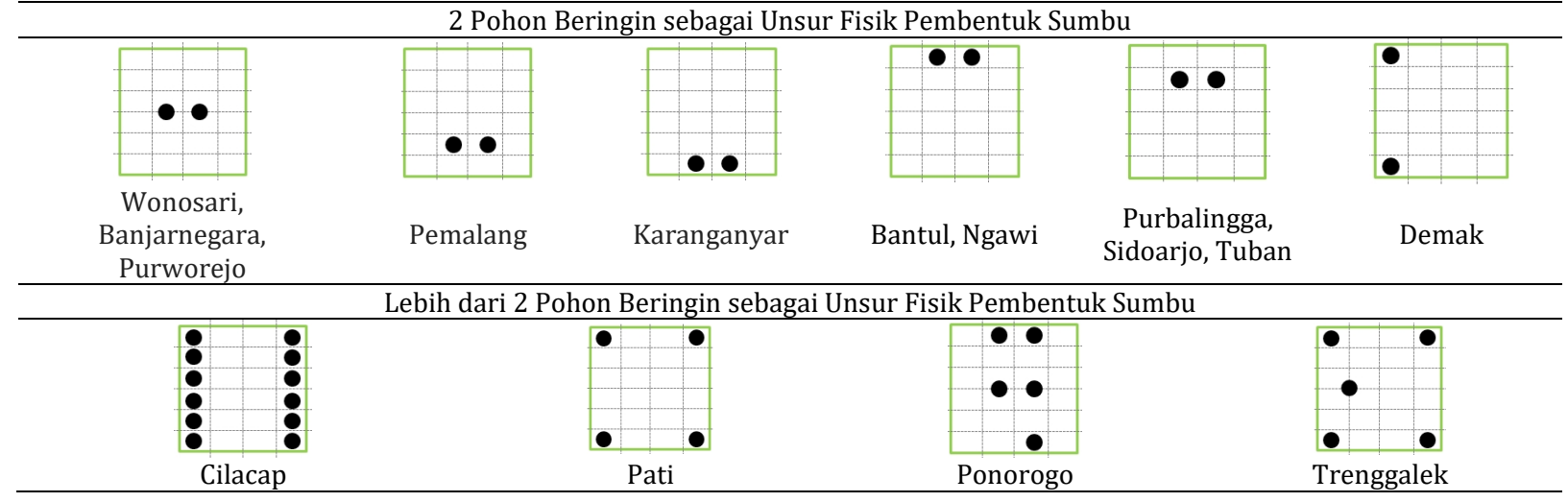

\subsection{Tiang Bendera}

Selain pohon beringin, terdapat tiang bendera sebagai unsur fisik pembentuk sumbu sekaligus bentuk transformasi elemen simbolik yang berada di dalam alun-alun. Tiang bendera dapat menjadi faktor penentu orientasi ruang melalui posisi peletakkannya ataupun saat kegiatan upacara berlangsung. Tiang bendera sebagai pembentuk sumbu tidak hanya ditemukan di dalam alun-alun, namun di luar alun-alun tepatnya pada bangunan yang mengelilingi alun-alun. Peletakkan tiang bendera pada bangunan yang mengelilingi alun-alun termasuk dalam pembahasan dikarenakan masih memiliki kaitan dalam memperkuat sebuah sumbu terjadi. Berikut ini adalah variasi peletakkan tiang bendera di dalam alun-alun maupun pada bangunan yang mengelilingi alun-alun.

Tabel 3. Posisi Tiang Bendera

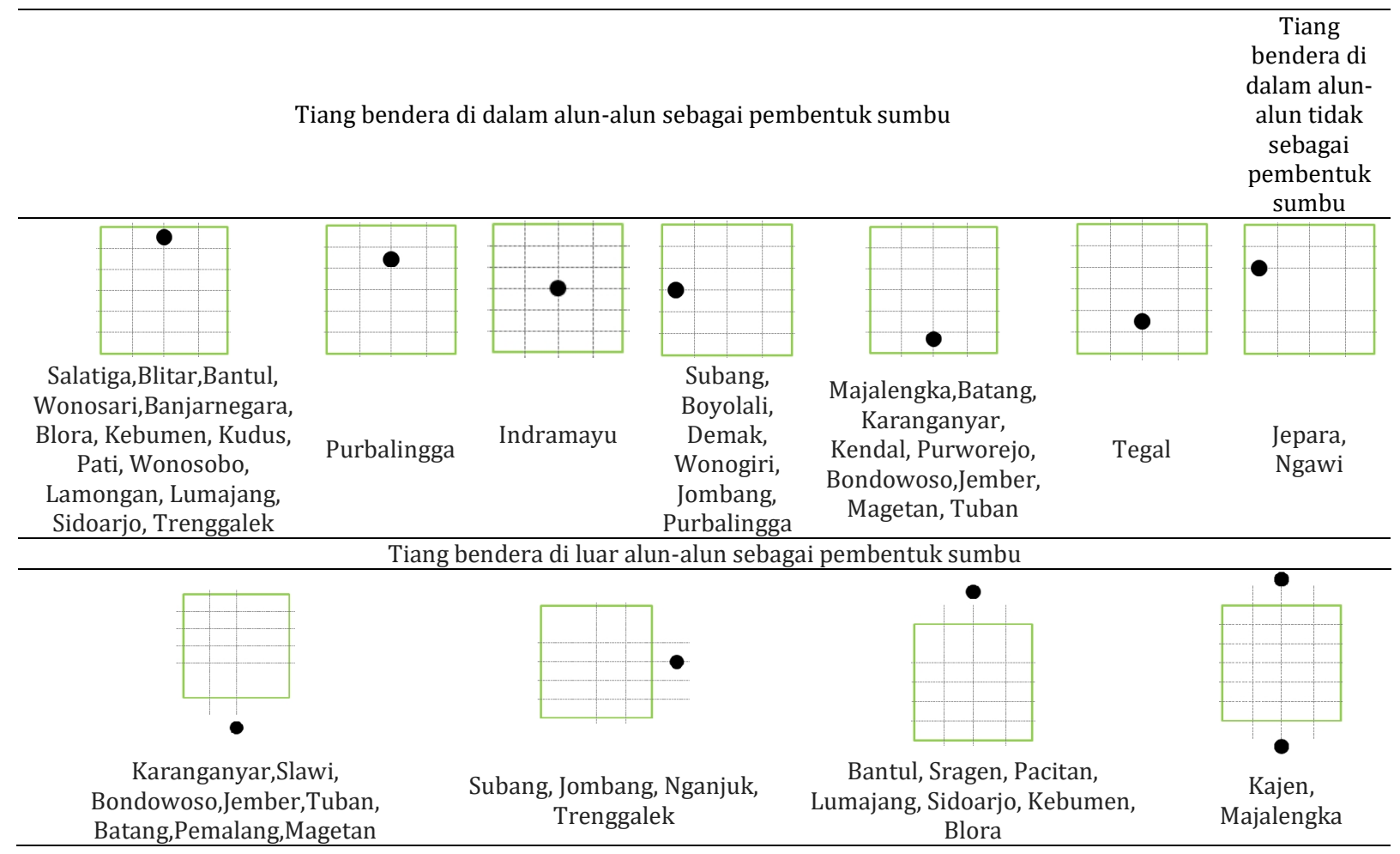


Tugu/monument adalah elemen simbolik selain pohon beringin dan tiang bendera yang berpengaruh pada pembentukkan orientasi. Peletakkan sebuah tugu/monument pada titik-titik tertentu memiliki tujuan tersendiri antara lain sebagai landmark di dalam alun-alun, sebagai elemen simbolik penyambut di area entrance ataupun sebagai landmark untuk pengguna jalan yang mengelilingi alun-alun. Tidak hanya di dalam alun-alun, tugu/monument di luar alun-alun juga mempengaruhi pembentukkan orientasi. Tugu/monument di luar kawasan dapat memperkuat ataupun tidak berpengaruh sama sekali sumbu yang mengikat antara pemerintah dan alun-alun. Sama seperti Yogyakarta, bahwa tugu/monument adalah salah satu unsur fisik pembentuk sumbu yang mengikat antara pemerintah dan alun-alun.

\section{Tabel 4. Posisi Tugu/Monumen}

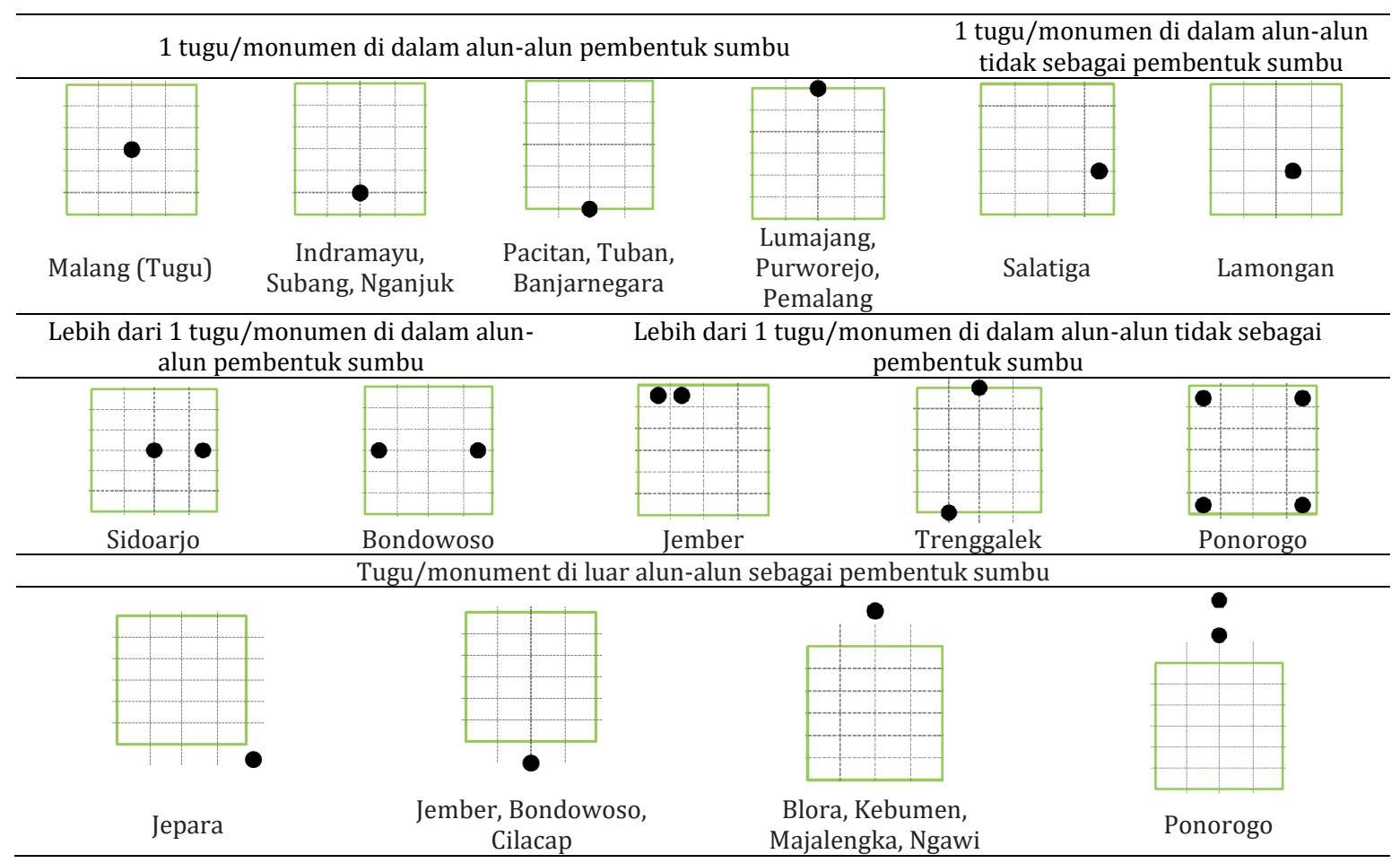

\subsection{Gerbang}

Gerbang pada masa lalu (dapat dilihat di Yogyakarta dan Surakarta) merupakan salah satu unsur fisik pembentuk sumbu. Gerbang pada masa lalu tidak terlepas dari benteng yang mengelilingi Keraton. Saat ini gerbang merupakan unsur fisik yang ditemukan pada area alunalun, dimana juga mempengaruhi sumbu dikarenakan gerbang memberikan arah pergerakkan dan arah pandang. Diibaratkan apabila gerbang berada di Utara dan Selatan maka arah pergerakan dan arah pandang pengguna alun-alun akan terbentuk Utara-Selatan. Selain itu gerbang juga memiliki sebuah hierarki, gerbang yang utama dan pendukung memiliki wujud fisik yang berbeda. Perbedaan hierarki tersebut tidak dapat diartikan gerbang utama lebih berpotensi membentuk sebuah sumbu, dikarenakan sebagian gerbang utama diletakan untuk merespon sisi alun-alun yang berhadapan dengan jalan raya utama/primer. Sehingga dapat disimpulkan bahwa gerbang saat ini berpotensi sebagai pembentuk sumbu tetapi tidak selamanya gerbang membentuk sebuah sumbu. 
Tabel 5. Posisi Gerbang

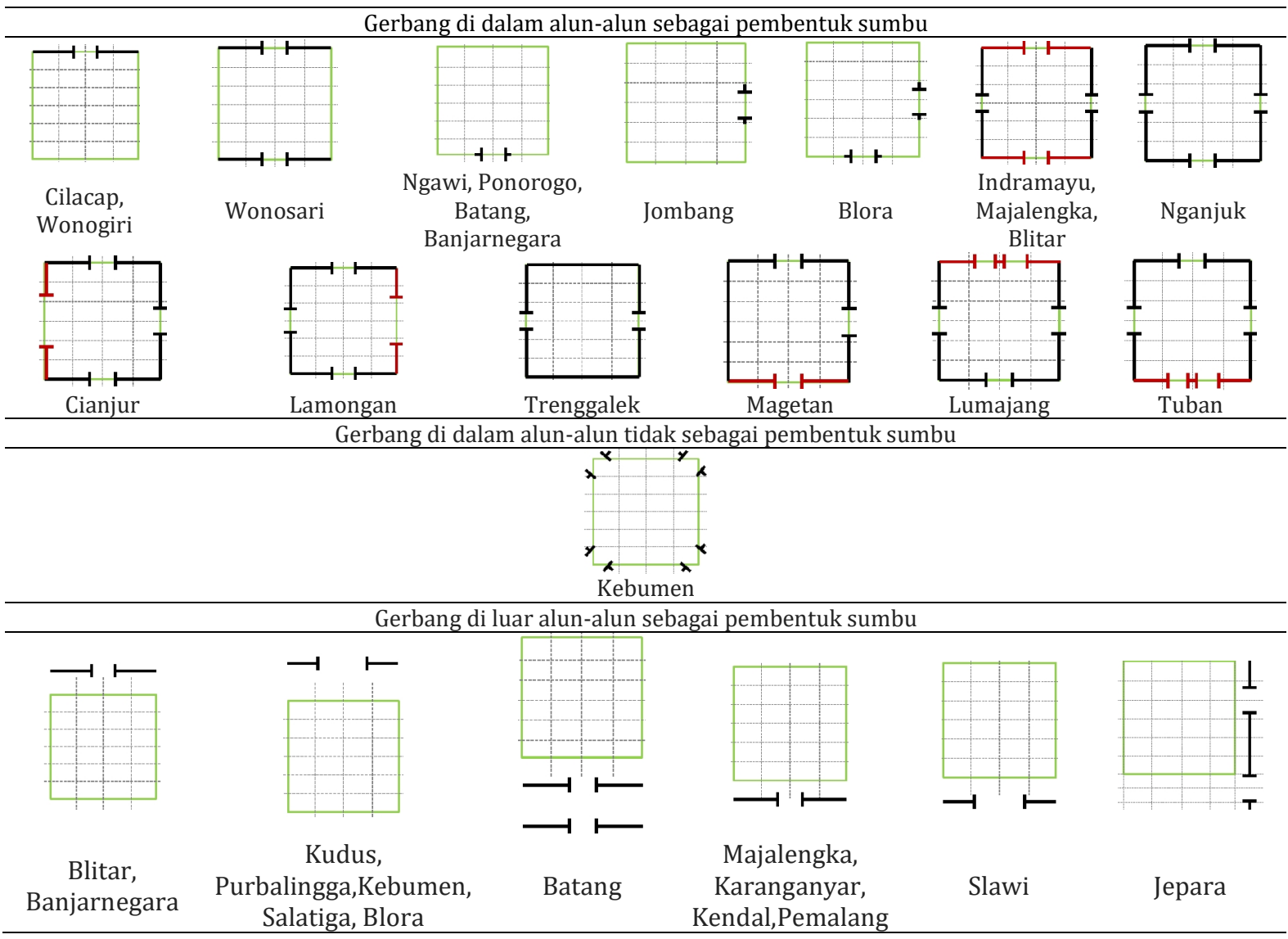

\subsection{Pengerasan tanah}

Pengerasan tanah juga dapat mempengaruhi orientasi ruang alun-alun, tergantung seberapa besar, dimana peletakkannya dan bagaiman betuknya. Pengerasan tanah pada alunalun saat ini ditujukan sebagai sebuah plaza pada titik-titik tertentu, sebagai jalur pedestrian, lapangan olahraga dan area masuk utama/entrance alun-alun. Pada hubungannya terhadap sebuah sumbu, pengerasan tanah yang berpengaruh adalah pada bagian entrance/area masuk alun-alun dan jalur pedestrian. Pengerasan tanah pada area entrance dapat menunjukkan sisi mana yang dianggap penting atau memiliki hierarki lebih tinggi, sehingga dapat membentuk sebuah sumbu apabila dilihat bersama dengan unsur fisik lainnya. Pengerasan tanah pada area entrance bersifat memberikan penekanan pada sebuah titik/setempat, berbeda dengan kasus berikutnya yaitu jalur pedestrian. Berikut ini adalah beberapa pengerasan tanah di dalam alun-alun Pulau Jawa yang masih bersandingan dengan pusat pemerintah. 
Tabel 6. Pengerasan Tanah di dalam Alun-Alun

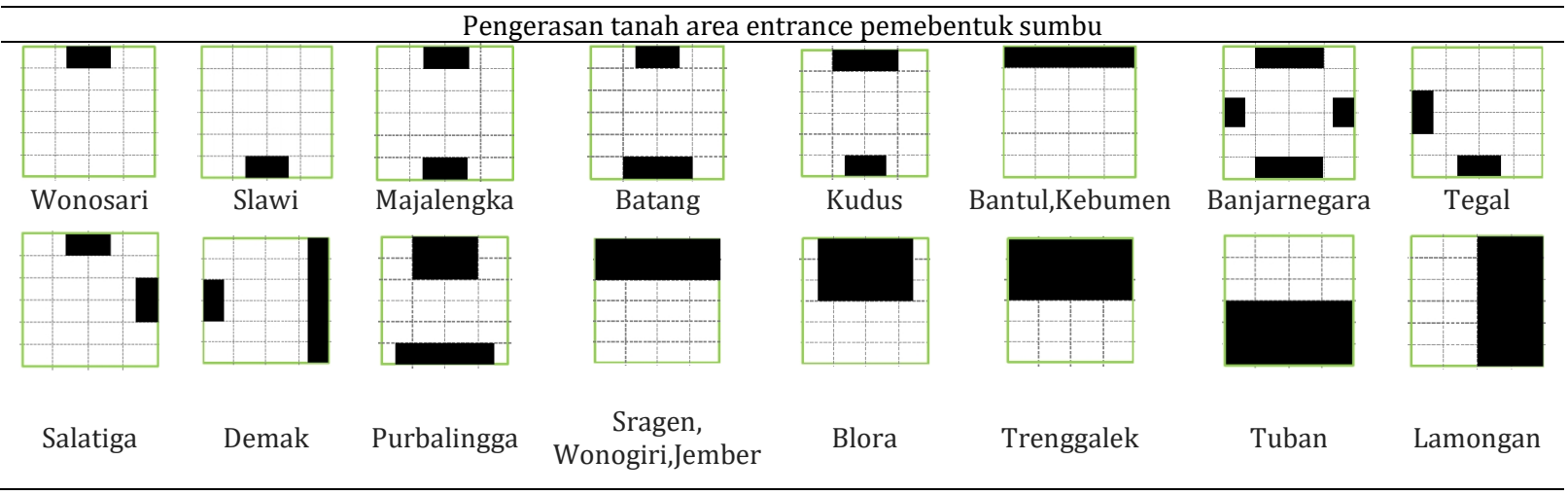

\subsection{Jalur pedestrian}

Jalur pedestrian juga terbentuk oleh sebuah pengerasan tanah seperti penjelasan sebelumnya, dimana mempengaruhi orientasi ruang alun-alun. Pada alun-alun saat ini jalur pedestrian terbagi atas tiga, yaitu jalur yang mengelilingi dan mengikuti bentuk alun-alun, jalur yang melintang Utara-Selatan dan Barat-Timur, serta beberapa kasus jalur yang membentuk pola baru pada ruang alun-alun. Jalur pedestrian yang berpengaruh pada pembentukkan sumbu adalah jalur yang melintang Utara-Selatan dan Timur-Barat. Berbeda dengan pengerasan tanah pada area entrance, jalur pedestrian lebih memberikan penekanan yang bergerak linear.

\section{Tabel 7. Jalur Pedestrian di dalam Alun-Alun}

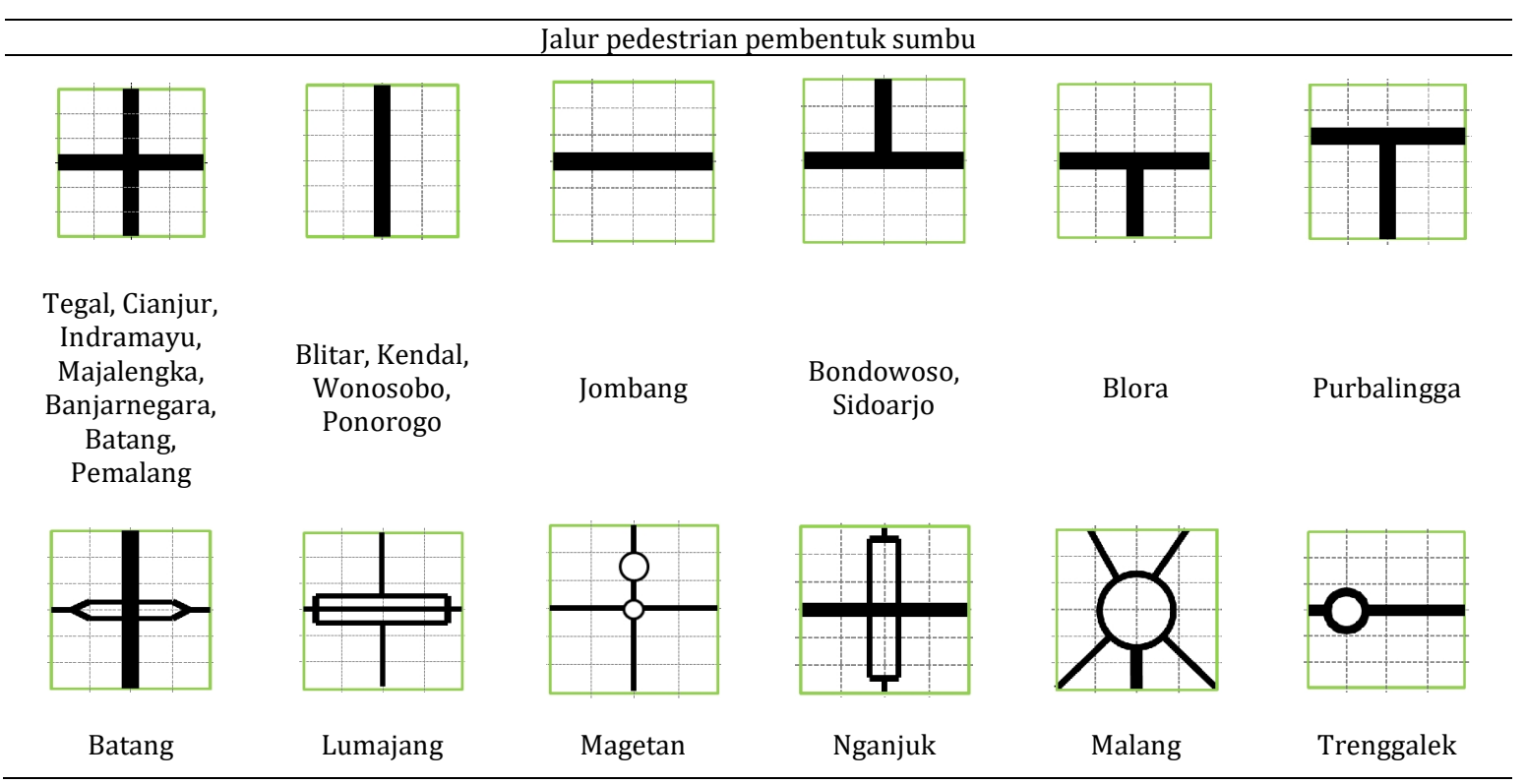

\subsection{Jalur kendaraan}

Jalur kendaraan sebagai pembentuk sumbu terbagi atas dua, yaitu yang melintang di dalam alun-alun dan tegak lurus sisi alun-alun. Jalur kendaraan tegak lurus sisi alun-alun yang memiliki fungsi jalan utama, memberi pengaruh lebih kuat terhadap pembentukkan sumbu dibandingkan jalan sekunder yang memiliki ukuran dan pergerakkan lebih kecil dari jalan 
utama. Jalur kendaraan yang melintang di dalam alun-alun berpengaruh besar pada pembentukan sumbu, dapat ditemukan pada dua kasus yaitu Cilacap dan Ngawi

Tabel 8. Jalur Kendaraan Tegak Lurus Alun-Alun

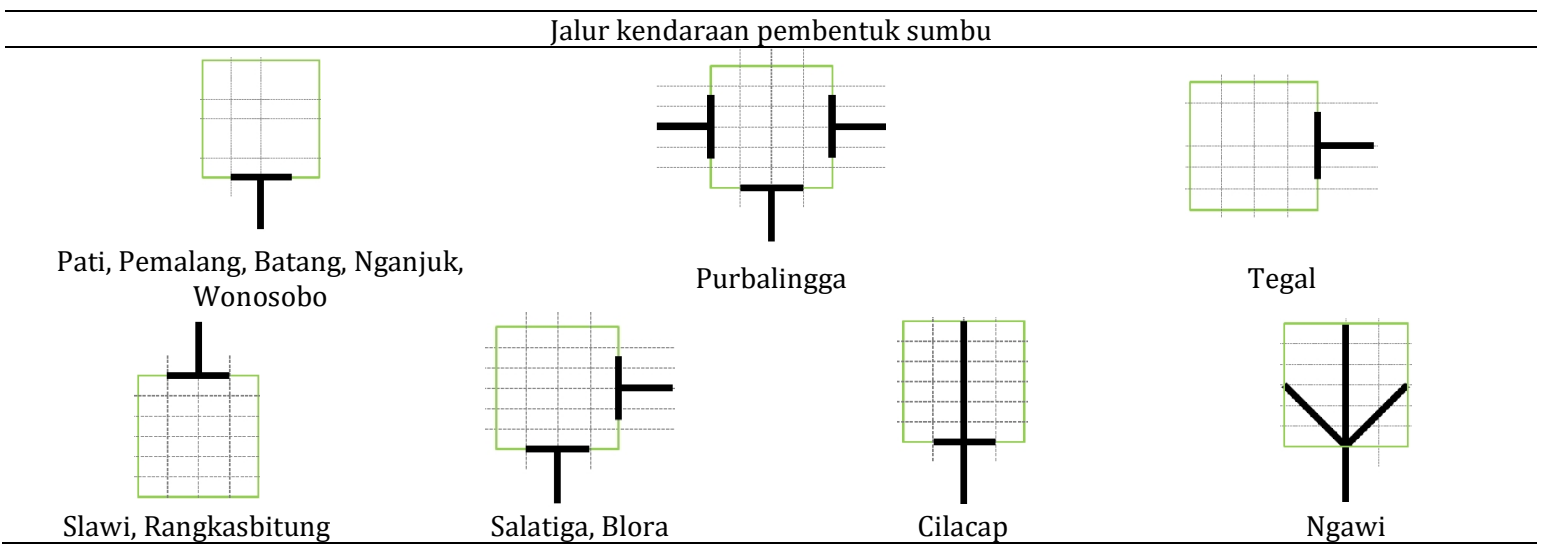

\subsection{Signage}

Keberadaan sebuah signage dapat dikatakan merupakan hal kecil yang berpengaruh dalam pembentukkan sumbu. Peletakkan sebuah signage (alun-alun ataupun pusat pemerintah) saat ini berada pada titik tengah dari sebuah bangunan pemperintah dan alunalun ataupun bisa berada pada sudut alun-alun. Signage berfungsi sebagai landmark dan juga sekaligus dapat memperkuat sebuah sumbu apabila disandingankan dengan unsur fisik lainnya. Berikut ini adalah beberapa temuan peletakkan signage di dalam alun-alun.

\section{Tabel 9. Posisi Signage}

Ngawi, Karanganyar,
Banjarnegara

\subsection{Pendopo di dalam alun-alun/gazebo}

Pendopo di dalam alun-alun atau sebagian sudah menyebutnya sebagai gazebo, mempengaruhi sebuah sumbu dikarenakan peletakkannya mengapit titik tengah dan berada pada titik tengah. Apabila dilihat dari fungsi nya ketika sebuah upacara berlangsung, pendopo alun-alun menjadi tempat para pemimpin bernaung dan peserta upacara menghadap ke arah pendopo alun-alun. Pada fungsi keseharian, pendopo digunakan sebagai tempat bernaung untuk berteduh dan beristirahat. Fungsi tersebut yang mengahasilkan beberapa alun-alun tidak lagi menggunakan atau menamainya dengan pendopo melainkan dengan sebutan gazebo. Penamaan pendopo dan gazebo memiliki hierarki yang berbeda, gazebo lebih mencirikan hal profane dengan sifat rekreasi sedangkan pendopo mencirikan hal lebih sakral 
dari sekedar tempat berteduh dan berisitrahat. Berikut ini adalah posisi pendopo di dalam alun-alun Pulau Jawa yang masih bersandingan dengan pusat pemerintah.

\section{Tabel 10. Posisi Pendopo di dalam Alun-Alun}

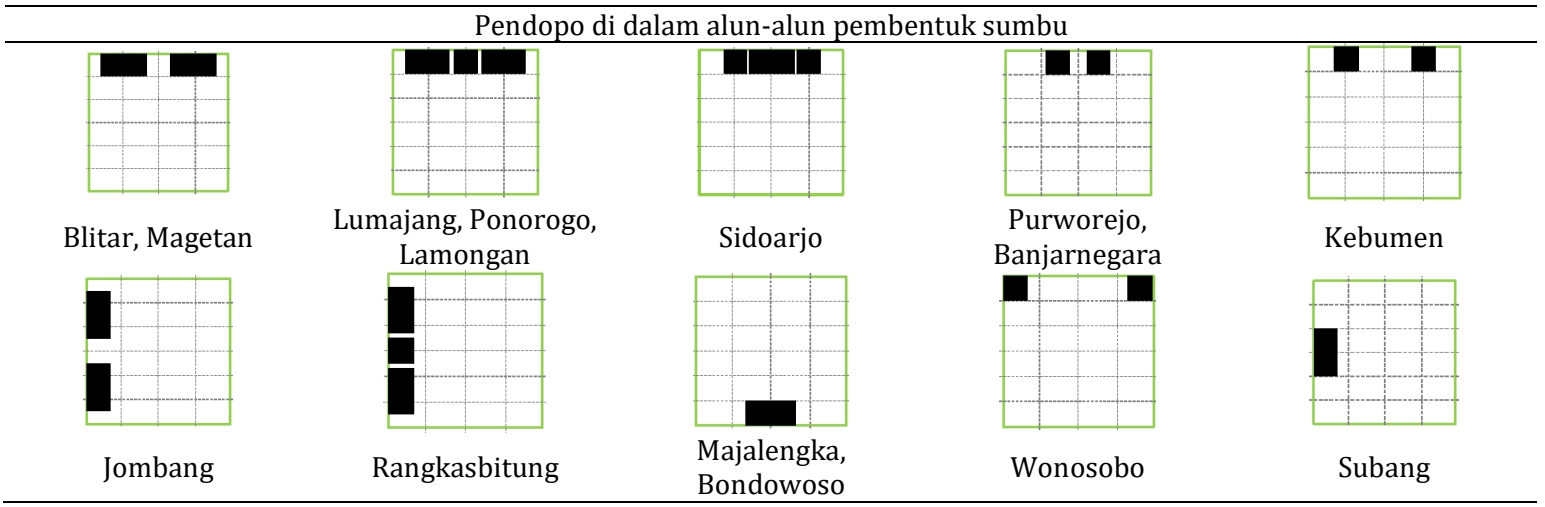

\subsection{Bangunan penting/bersejarah}

Bangunan penting/bersejarah merupakan unsur fisik di luar alun-alun yang mempengaruhi sebuah sumbu. Hal tersebut dikarenakan saat ini, bangunan penting/bersejarah memiliki nilai yang tinggi dilihat dari kesejarahannya. Bangunan penting/bersejarah dapat berupa bangunan bekas peninggalan masa lalu ataupun bangunan keagamaan seperti Masjid.

\section{Simpulan}

Revitalisasi alun-alun seiring perkembangan kota tidak sekedar menambahkan unsurunsur fisik sebagai pelengkap sarana/prasarana kegiatan sosial dan ekonomi. Peletakkannya di dalam alun-alun sudah ditentukan untuk memperkuat orientasi ruang. Secara keseluruhan alun-alun yang masih bersandingan dengan pusat pemerintah di Pulau Jawa masih berorientasi terhadap sebuah sumbu. Akan tetapi terdapat perbedaan dengan masa lalu bahwa saat ini unsur fisik pembentuk sumbu terdiri dari elemen simbolik ataupun pengolahan bentuk fisik seperti pohon beringin (sebagai unsur fisik pembentuk sumbu yang bertahan), tiang bendera, tugu/monumen, gerbang, pengerasan tanah, pedestrian way, jalan kendaraan tegak lurus maupun memotong alun-alun, signage dan pendopo/gazebo di dalam alun-alun. Unsur fisik yang berada di titik tengah alun-alun dalam garis Utara-Selatan maupun Timur-Barat memperkuat sebuah sumbu, namun unsur fisik yang berada di sudut ataupun tidak di titik tengah dapat merusak orientasi ruang di dalam alun-alun. Mempertahankan alun-alun kiranya tidak sekedar sebuah nama atau secara fisik saja namun memperhatikan ketetapan ataupun perlambangan yang berlaku pada ruang terbuka tradisional Jawa di masa lalu, sehingga sebuah ruang memiliki identitas dari kebudayaan yang berlaku di dalamnya dan bukan tampilan fisik.

\section{Ucapan Terima Kasih}

Ucapan terima kasih kepada Dr. Y. Kusliansjah. Ir. MT. sebagai pembimbing utama dalam penelitian alun-alun di Pulau Jawa yang berlangsung dari Januari hingga Agustus 2017. Penelitian besar tentang alun-alun di Pulau Jawa juga dapat terlaksana atas bantuan tokohtokoh masyarakat di setiap kota (yang disebutkan dalam penelitian ini) dalam memberikan informasi maupun data-data yang tidak dapat ditemukan dalam buku maupun internet. 


\section{Daftar Pustaka}

Aramita L.M, Ayesha. (2017) The Cultural Relationship of Alun-Alun and Government Complex in Java Today. A Thesis submitted for the degree of master of architecture, Parahyangan Catholic University.

Damayanti, Rully., Handinoto. (2005). Kawasan "Pusat Kota" dalam Perkembangan Sejarah Perkotaan di Jawa, Jurnal Dimensi Teknik Arsitektur, Vol.33, No.1, 34-42.

Drajat, Satrio Utomo. (2008). The Rationale behind Urban Form of The Javanese Inland Cities. Thesis - Master of Arts in Architecture, National University of Singapore.

Handinoto. (1992). Alun-alun sebagai Identitas Kota Jawa, Dulu dan Sekarang, Jurnal Dimensi, 18/ARS, 1-15.

Habraken, N. J. (1983). Transformation of the Site. Cambridge, Massachusetts: A Water Press.

Habraken, N. J. (1998). The Structure of the Ordinary. Cambridge, Massachusetts: The MIT Press.

Karsono, Bambang., Wahid, Juliaihi. (2008). Imaginary Axis as a basic Morphology in The City of Yogyakarta - Indonesia. $2^{\text {nd }}$ INTERNATIONAL CONFERENCE ON BUILT ENVIRONMENT IN DEVELOPING COUNTRIES, 187-195.

Moerdjoko. (2005). Alun-Alun Ruang Publik Bersejarah dan Konservasi. Jakarta : Usakti.

P. Wiryomartono, A. Bagoes. (1995). Seni Bangunan dan Seni Binakota di Indonesia - Kajian mengenai konsep, struktur dan elemen fisik kota sejak peradaban Hindu Buddha, Islam hingga sekarang. Jakarta: PT. Gramedia Pustaka Utama.

Suryo, Rony Gunawan., Soewarno, Nindyo., Ikaputra., Setiawan, Bakti., et. al. (2011). Morphological Study of Colonial and Traditional Urban Space in Java. Biennale International Conference on Indonesian Architecture and Planning.

Widyastuti, Dyah. (2012). Memorable Square : Identities, Meanings and the Production of Urban Space in Yogyakarta, Indonesia, Procedings REAL CORP Tagungsband 14-16 May, 12911300. 


\section{Lampiran}

Metoda Pengamatan : identifying level setiap unsur fisik pada nominal classes yaitu, major arteries, roads, building element, partitioning, furniture dan body\&utensils.

Ket.(beberapa contoh kasus studi)
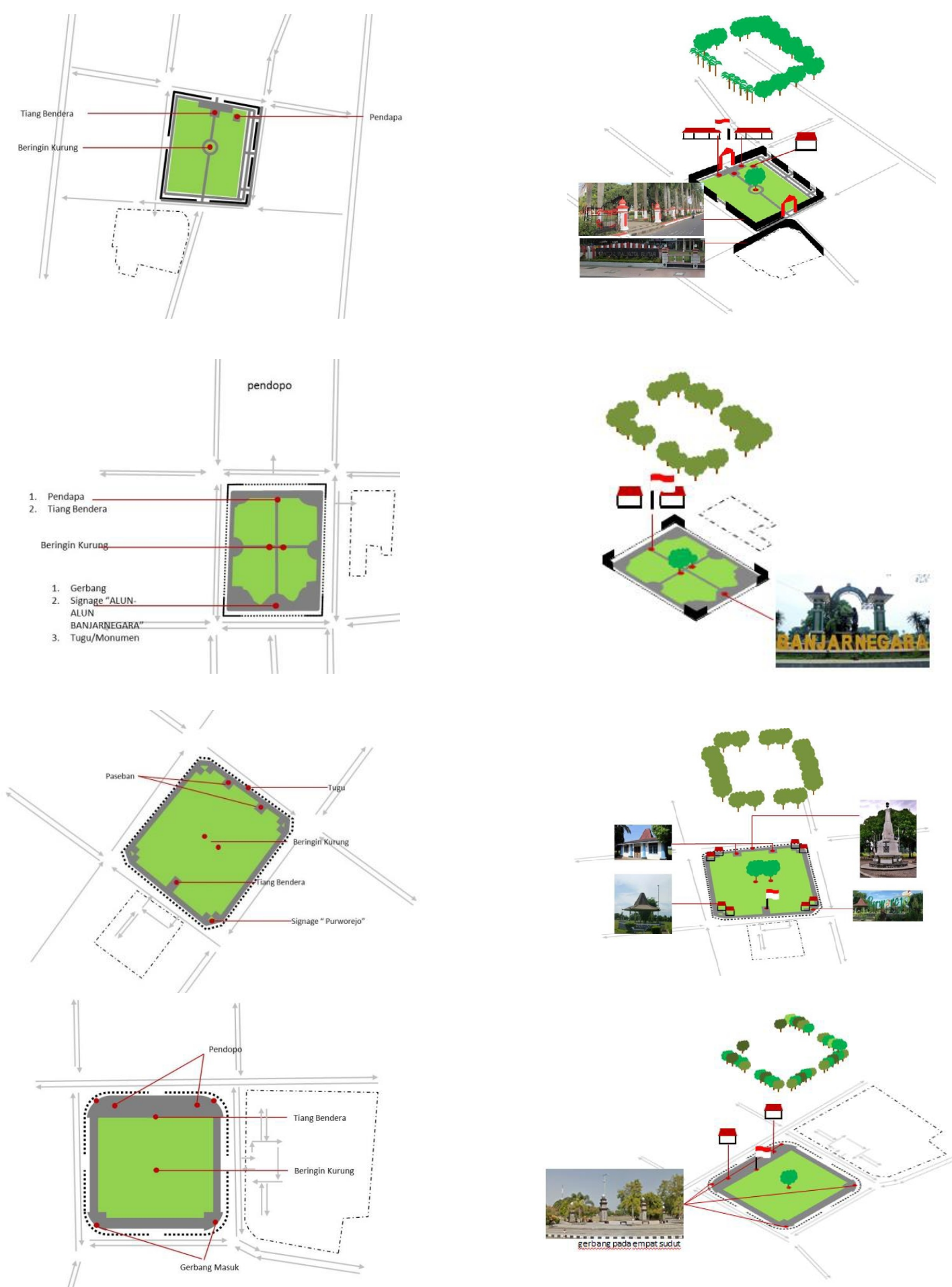